\title{
Rabbinsk tænkning, mystik, psykokabbalisme og postmoderne tekstteori
}

I det følgende vil jeg diskutere nogle ligheder mellem rabbinsk exegetisk metode og moderne tekstteori, der kan få én til overveje om ikke det, der umiddelbart tager sig ud som originale skridt i åndslivets progression, måske rettere er en art judæisk eruption i vor græco-kristne kultur. En eruption, der har produceret en metafysisk hybrid, vi kan kalde psykokabbalisme. Jeg vælger i denne forbindelse at inddrage Derrida, Barthes og Freud, da deres rabbinske indflydelse er »sløret« i modsætning til en person som Bloom, der rent ud erklæærer sin kritiske metode kabbalistisk. ${ }^{1}$

\section{Rabbinsk Metafysik}

For rabbineren er Torah det, Gud gav Moses på Sinai. Der er en mundtlig Torah og en skriftlig; den skrevne er nedfældet i de fem Mosebøger. Torah er dog mere end en historisk beretning eller oprindelsesmyte. Opfattelsen er den, at Gud selv studerer Torah ganske som en entreprenør studerer en arbejdstegning, inden han bygger et hus.

$\gg$ Den Hellige, velsignet være at han gjorde det samme [som entrepren $\varnothing$ ren]. Han skuede i Torah'en og skabte derpå verden. $\ll^{2}$

Den store Kabbalist Rabbi Mosche ben Nachman (HaRamban, Nachmanides) (1194-1270) forklarer i sin Torah-kommentar, at idet Gud gav mosebøgerne til Moses, investerede han i dem al visdom. Denne visdom er dels eksplicit, men mestendels implicit - $\mathrm{i}$ ordenes numerologiske værdi, deres relation og ikke mindst ordenes og bogstavernes fremtræelelsesform m.v. En særlig dekryptografering af Torah er derfor essentiel for at erkende Torah, Guds plan. Denne 
opfattelse er ikke ny med Nachmanides, men i overensstemmelse med traditionens.

Den rabbinske metafysik er ekstremt grafocentrisk. Kabbalah ${ }^{3}$ lierer, at Det Første var Ordet i den forstand, at Gud satte sit navn (YHVH, Jahve) på det oprindelige intet, og ud af det ord sprang så hele det hebraiske alfabet. ${ }^{4}$ Fra alfabetet sprang adskillige skabelser, eller skabelseslag, idet den første ikke kunne rumme hele den guddommelige energi; energien gennembrød da denne skabelse og skabte en ny og så fremdeles: den, der beskrives i Genesis, er den sidste. De tidligeste kabbalister talte om fire universer repræsenteret ved de fire bogstaver i YHVH. Rabbi Isaac Luria antydede, at der eksisterede et femte univers reprasenteret ved Yod, og at der i dette eksisterede endnu fïre reprasenteret ved hvert bogstav i tetragrammaton (YHVH).

Af grafemet og fonemet er det altid grafemet, der udgør det principielle element $\mathrm{i}$ rabbinsk hermeneutik ${ }^{5}$. Den rabbinske indfaldsvinkel til visdom vil altid vare grafocentrisk og ikke ontocentrisk eller logocentrisk. Væren er udgået af ordet, ikke omvendt. Religionens største imperativ for rabbineren var, og er, derfor interpretatio. ${ }^{6}$

\section{Kryptogrammatologi-rabbinsk hermeneutik}

Diskuterer man en religions hermeneutik, må man gøre sig det klart, at selv om $\gg$ hermeneutik « lyder troskyldigt nok, så vil exegesens plads i en religiøs institution altid vare, at den skal bevise to ting: 1) teksten har ret, 2) vores tro er bekraftet af teksten som den sande. Jo mere kryptiske de hermeneutiske metoder bliver, jo mere kan det tjene til at dække den teologiske selvretfaerdiggørelse. Udmønter den hermeneutiske operation sig ikke i et entydigt udsagn, men en polysemisk relation, så sikres selvfølgelig, at den teologiske dogmatiker får det sidste ord. Bærer vi denne funktion in mente, kan vi studere den rabbinske hermeneutik uden at forblindes af en naiv begejstring for rabbinernes imponerende sans for intertekstualitet og polysemi.

Rabbinerne har utallige tolkningsprincipper, men af disse regnes de tretten middot for de vigtigste. De er fremsat af Rabbi Ishmael omkring år 100, men havdes alligevel, som al anden Midrash, at vare givet Moses på Sinai. Som gudsgivne bliver de hermeneutiske metoder indiskutable; man har kun valget, om man skal bruge den ene eller den anden og pă hvilken måde. Handelman pointerer, ${ }^{7}$ at den vestlige videnskabs begreber altid er konklusioner: ideer, der udgør det endelige resultat af spekulation eller iagttagelse. For rabbinerne derimod kan intet begreb nogensinde vare endeligt, da et sprogtegn eller skriftsted ikke kan afgræenses definitivt, men afhænger af et samspil med andre 
sprogtegn, skriftsteder - man vil altid kunne relatere til endnu et skriftsted og udvikle nye betydninger af deres samspil. Ydermere er det en naturlig del af Torah, at fortolkninger af samme passage kan modsige hinanden ud fra den intertekstualitet, der inddrages.

Rabbinsk exegese synes at have tre forudsatte principper: 1) Teksten er guddommelig og rummer derfor ingen selvmodsigelser eller overflødigheder. 2) Teksten forklarer sig selv. 3) De exegetiske principper er selv udledt fra den tekst, de anvendes på, og er derfor gudsgivne. Hele udgangspunktet sikrer derfor, at uanset hvor mange hermeneutiske metoder, der udledes, og på hvor mange måder og i hvor mange sammenhenge, de tages i anvendelse, så vil der altid være garanteret en enhed og helhed over resultatet: det er alt sammen Torah.

Samely ${ }^{8}$ har gjort et banebrydende arbejde med at systematisere rabbinernes hermeneutiske principper uden at ty til den nemme løsning at nøjes med de 13 middot. Han finder at mindst tre overordnede kategorier er i brug:

1. Den tekstens enhed, der er mălet for exegesen, kan tilhøre fire klasser:

a) individuelle bogstaver og bogstavgrupper, hvis morfemiske eller lexemiske identitet suspenderes;

b) morfemer eller ord;

c) paragraffer eller sietninger;

d) større tekstafsnit.

Klasse a) må uddybes lidt, da det ikke er noget, man i vesten kan nikke genkendende til. Han finder, at klasse a) kan opdeles i syv underkategorier:

Bogstavets form, dets navn, dets numeriske vardi, dets plads $i$ alfabetet, dets akronymiske vardi, dets reprasentative vardi i et sekundart alfabet og dets lydlige vardi.

2. Tegnenes indbyrdes forhold kan tilhøre tre grupper, der udg ør forskellige udgangspunkter for exegesen:

a) positionen af den tekstuelle enhed, der er exegesens mål;

b) identitet (hel eller delvis) af en mål-enhed med en anden, d.v.s. synonymi og hyponymi;

c) forskelle mellem mål-enheden og en anden enhed.

3. Flere skriftsteder placeret forskellige steder kan inddrages med hensyn til mål-enheden, og hver kan inddrage sin exegetiske operation, sådan at den samlede operation bliver på én gang multi-lokationel og multi-operationel. 
Kal vehomer er vist det eneste princip, der på nogen måde ligner en logik; det synes at være det eneste princip, der tillader en analytisk reduktion af tekststedet til præmisser. De andre sammenstiller citater og genererer parafraseringer af teksten.

Kal vehomer adskiller sig radikalt fra syllogismen ved ikke at beskieftige sig med forholdet mellem kategorier," men ved at være baseret på hvis og følgeslutningen så meget desto mere er det sikkert at... Man kan formalisere princippet således: 'Hvis $X$ (der mangler $A$ ) har $Z$, så meget desto mere sikkert er det, at $Y$ (der har A) har Z.' Sietningerne i parentes er ikke en del af grundprincippet, men kendetegner den udvidede kal ve-chomer. Handelman bemærker:

"I det klassiske eksempel på en syllogisme 'Alle mennesker er dødelige, Sokrates er et menneske; ergo er Sokrates dødelig' er det vigtige skridt at vise, at Sokrates tilhører en bestemt klasse (mennesket). I kal vechomer er det vigtige mellemtrin ikke at vise, at $\mathrm{Y}$ er en del af klassen $X$, men at $Y$ er som $X$ (blot endnu mere så), hvorfor det må gælde, at hvis X har Z, så har Y det også - ikke at $\mathrm{Y}$ er X er Z. Dette blot endnu mere $s a ̊$ afhenger af en lighedsperception, at man øjner ligheder trods forskelle (ikke et bortfald af forskelle), og det leder ikke til priedikative udsagn, hvor kopula er er, men til en inddragen uden identitet. $\ll^{\prime \prime \prime}$

En viesentlig forskel mellem »vestlig« og »rabbinsk« t:enkning er endvidere, at »vestens « pradikative klasser må orienteres om subjektets kvaliteter og $s \emptyset$ ger dets indplacering i hierarkiske kategorier, hvorimod »rabbinernes« tænkning er baseret på strukturel relation mellem fremsættende sætninger og ikke på hierarkiske kategorier. For at den strukturelle sammenstilling kan have gyldighed, må rabbinerne derfor orientere deres argumentation omkring verber, adverbier m.v. og ytringens potentielle bibetydninger. Rabbinerne vil deducere ud fra strukturel sammenstilling, at X er ligeså $Y$-agtig som $Y$, eller endda mere $Y$-agtig. Hvorimod klassisk logik vil deducere ud fra generel prædikativ lighed, at $\mathrm{X}$ er en del af $\mathrm{Y}$. Rabbineren vedkender sig sin argumentations flertydighed og foruddefinerer sin hermeneutiske operation som relativ (den er menneskelig) i forhold til den absolutte tekst (der er guddommelig). Og med den nødvendige »lighedsperception « medtænker de samtidig usikkerheden i denne menneskelige fatteevne: hvem siger, at man har fundet det rette lighedsprincip? Derfor vil rabbinsk hermeneutik altid virke famlende, og den vil med afsæt $\mathbf{i}$ andre tolkningsprincipper og andre skriftsteder fors $\varnothing g e$ at finde ud af, om det nu er det ene eller det andet valg af lighedsprincip, der er mest gyldigt i pågaldende tilfielde. 
Binyan av: Dette er en form for induktion, hvor man slutter fra et specifikt tekststed til en generel regel. Når der i teksten f.eks. står, at man ikke må tage en møllesten i pant, så slutter binyan av, at man ikke må tage noget i pant, som er nødvendigt for, at et menneske kan tilberede sin føde.

Gezerah shavah: Dette er et rent lingvistisk princip derved, at to passager, der udtrykkes med samme sætningskonstruktion, tillægges analogt betydningsindhold. Den analogi, man tillægger de to passagers mening, tager altså intet hensyn til indholdet, men alene til strukturel lighed.

Gematria: Hebraisk bruger bogstaver til at betegne tal. Omvendt tillægges tal semantisk funktion; f.eks. ved at ord eller passager med samme tal menes at betyde det samme. F.eks. får man af $\gg$ Eliezer «, Abrahams tjener, tallet 318. 318 er det antal soldater, Abraham sendte i krig (1. Mos. 14,14), hvoraf gematria konkluderer, at Abraham kun sendte én person i krig: Eliezer. ${ }^{11}$

Notarikon: Dette princip bryder ord op i dets enkeltdele og lader fortløbende tekstanalyse tage udgangspunkt i de derved fremkomne dele eller bogstaver. Alle ord opfattes således som akronymer eller chiffre. Og da de ord, de er akronymer over, selv er akronymer, bliver chiffersystemet endeløst.

Semukhin: Semukhin tillægger sammenstilling en semantisk funktion. Handelman giver et udmærket eksempel på semukhin: 2. Mosebog sammenstiller beretningen om, hvordan tabernaklet blev bygget $(2$.Mos.25,8-31,12) med budene om at overholde sabbatten (sammesteds 31,13-17). Semukhin udlægger den sammenstilling sådan, at siden 39 arbejder var nødvendige for at bygge tabernaklet, er det arbejde, der er forbudt på sabbatten, de selvsanme 39 typer. En sådan udlægning retfærdiggøres primært af, at siden teksten er Guds ord, så er intet i den tilfældig, heller ikke sammenstillinger.

Stern kritiserer Handelman for at se semukhin som udtryk for en generel forskel mellem rabbinsk og græsk metode. ${ }^{12}$ Hun opfatter det således, at rabbinsk metode bygger på strukturel relation koblet med et tematisk element gentaget i begge passager; dvs. en lighedsrelation, f.eks. »arbejde «. Den klassiske græske logik bygger derimod på prædikative træk i den forstand, at den ene passage erklærer, at det forholder sig sådan eller sådan med noget nævnt i en bestemt passage. Der er således tale om en radikal forskel $i$, hvordan semantisk kobling etableres. Den »græske« er prædikativ, kategoriel, og den rabbinske er mere uigennemskuelig. Handelman, ud fra Jacobs, vil gerne kategorisere den som propositionel og relationel, modsat ontologisk og relationel (der kendetegner den græske metodik), men det er nok for simpelt. Vi skal passe på at bruge dichotomier, der har vores egen logik som forudsæetning, til at kategorisere rabbinernes metodik. Rabbinsk metodik synes mere at kunne kendetegnes ved semantisk translokation baseret på lighedspincipper. Det for 
os interessante ved dette er, at »semantisk translokation « selvfølgelig er det princip, der gør sig gældende i metaforen!

Vi må medgive Stern, at man ikke kan konkludere, at ovennævnte distinktion galder alment for rabbinsk logik, blot fordi det galder for ét tolkningsprincip (semukhin). Men Stern kritiserer en sådan udlægning på det grundlag, at hele idéindholdet $\mathbf{i}$ semukhin er, at teksten er fra Gud, og at der derfor er givet en mening i enhver tilsyneladende meningsløs sammenstilling (og iøvrigt alt andet), samt at det er rabbinerens fornemmeste opgave at bevise det, ved at udfinde den sammenhæeng. ${ }^{13}$ Bemark at metodikken skal tjene netop dét, jeg ovenfor angav som et problem med at analysere religiøs exegetisk metodik: det skal bevise skriftens absolutte autoritet og bruge det beviste til at bevise dogmatikkens opfattelse deraf. Om teksten anskues som guddommelig eller ej, vedkommer dog slet ikke sagen, da guddommeligheden alene tjener rabbineren til at retfærdiggøre, at han overhovedet anvender sin saerlige hermeneutiske metode på noget tilsyneladende tilfæuldigt og ubetydeligt. Kritikken er ugyldig og vi må derfor ende med at medgive Handelman og Jacobs, at deres distinktion synes at have nogen gyldighed.

\section{Torah og midrash; Talmud, mishnah og gemara - og kabbalah}

De rabbinske kanoniske skrifter blev endeligt defineret i ca. år $450 \mathrm{f} . \mathrm{Kr} .,{ }^{14}$ og udgør det, vi kender som Det gamle testamente. Jøderne kalder Det gamle testamente ved et akronym: Tanakh d.v.s. Torah, Nebiim, Ketubim, (Mosebøgerne, Profeterne og Skrifterne). Bemark at vi her i Ta-na-kh har et klassisk eksempel på det rabbinske chiffersystem: at ordet i sin bogstavstruktur må rumme det, der uddyber dets betydningsindhold; det kan f.eks, som her, vere som et akionym.

Torah er umiddelbart set jødernes navn for Mosebøgerne, men begrebet går videre end som så. Talmud (studie) er den samlede miengde kommentarer til Torah, ${ }^{15}$ og de rummer den mundtlige Torah. Midrash (søgen, exegese) udgør den exegetiske tradition, og dens skrifter, med hensyn til Torah. ${ }^{16}$ Midrash betegner ikke kun fortolkning i vanlig forstand, da dens tekst er skrevet med Torah og er Torah - og er altså ikke blot om Torah. Talmud er selvfølgelig et stort kompleks af skrifter, hvis hovedbestanddele er Mishnah og kommentarerne til Mishnah: Gemara. Mishnah er, til forskel fra midrash, ikke direkte knyttet til biblen (den starter f.eks. med at diskutere, hvornår man skal sige aftenbøn og slutter med at diskutere, på hvilket tidspunkt honning i bistader kan anses for uren). Mishnahs status i forhold til Torah kan derfor være mest 
interessant for os at forstå, da vi i almindelighed ville klassificere den som sekundar, metatekst, mens rabbinerne anser også den for primærtekst. Mishnah blev iøvrigt systematiseret i de første århundreder e. Kr. og nedfældet ca. år 220. Neusner skriver:

»[..] Tractaten Avot [..] fremstiller en bemærkelsesværdig pointe. Torah fra Sinai er videregivet i en ubrudt linie fra Moses via Joshua og videre ... til de skriftkloge, der citeres i selve Mishnah. Torah er givet til Israel også ud over skrifterne. Hvad de skriftkloge lerer i Mishnah er Torah. De skriftkloge i Mishnah står i en lige linie til Sinai. Mishnah, der rummer deres belæringer, udgør en del af Torah åbenbaret af Gud til Moses

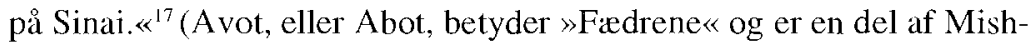
nah.)

Rawidowicz ${ }^{18}$ forklarer, hvordan den mundtlige Torah var en anden begyndelse for Israel, idet den mundtlige og den skrevne indgik i en debat om, hvilken status metatekst skulle have til primærtekst; metateksten vandt og fik status af primærtekst. Mishnah er selv blevet gjort til genstand for kommentarer; de er sammenfattet under navnet Gemara, der således udgør en kommentar til kommentaren. Desuden er to skolers kommentarer til Gemara og Mishnah integreret i Talmud, Rashi (Rabbi Schlomo Yitzhaki) hhv. Tosafot (Rahis svigersønner og børnebørn).

Talmud har siden 1520 haft en principiel typografisk opsatning, der i sig selv illustrerer den idé, at alt ex Torah. Hver side er sat op med et stykke fra Mishnah i centrum efterfulgt af Gemara's diskussion og kommentar. Ved siden af er kommentarerne trykt; på den ene side Rashi og på den anden Tosafot. Disse kolonner kan ydermere afgrænses af en rakke tilføjede noter, krydshenvisninger, ordforklaringer, uddybninger og kommentarer af senere autoriteter. Notér iøvrigt, at denne opsætning pricipielt er den, Derrida har lagt til grund for opsæetningen af sin bog Glas og måske også Tympan; det kan derfor undre, når Derrida fraskriver sig rabbinsk indflydelse på sin filosofi. ${ }^{19}$

Kabbalahs historie fortaber sig tilbage i tiden; det har været hemmeligholdt og dets udspring er dunkelt. ${ }^{20}$ Men af fremtradende tidlige talmudiske skoler, der kan betegnes kabbalistiske, er Hekhalot, Sefer Yetzirah og Bahir, der etableredes omkring det første århundrede efter Kristus, d.v.s. i den tidlige talmudiske periode. Bahir er skrevet af Rabbi Nehuniah, der i følge Talmud ${ }^{21}$ blandt andet underviste Rabbi Ishmael ben Elisha, yppersteprast ved det Andet Tempel. Kabbalismen fungerede altså dengang som ypperstepræstens læremester. Det er væsentligt, at Talmud således etablerer Bahirs, og dermed Kabbalahs, autoritet som Torah. 


\section{Kabbalah vs. mystik}

Kabbalah er esoterisk Midrash, eller rettere okkult teologi i modsætning til Den Mystiske Teologi; sidstnævnte begreb er naturligvis de kristne mystikeres betegnelse for deres metafysik og epistemologi. ${ }^{22}$ Det er vigtigt at forstả de forskellige motiver og mål, mystikeren og kabbalisten har for deres søgen: kabbalisten søger ikke en ontologisk enhed med Det Ene/Gud, som mystikeren jo søger, men s $\emptyset$ ger profetisk indsigt og profetiske evner. Mystikerens enhed med Gud er i rabbinerens øjne at ville gøre sig til Messias, hvilket selvf ølgelig for ham er principielt umuligt og en kxttersk tanke; rabbineren accepterer kun profetens midlertidige og medierede forbindelse med Gud i den profetiske henrykkelse; det er dén, kabbalisten vil finde veje og metoder til at nå.

Vi må hér huske den kabbalistiske belæring om ispaklaria, et spejl eller en linse, der forklarer, at selv om man ser Guds storhed og stråleglans, så er det altid gennem en linse eller som en refleks, aldrig direkte, umedieret. Ispaklaria er et af de forhold, der skiller kabbalah fra mystik. Okkultisme vedrører, som kabbalah, de skjulte verdener samt deres væesener og kræfter. Begrebet mystik er et fejlplaceret begreb i forbindelse med rabbinsk metafysik, for mystikeren har ingen interesse i de skjulte verdener eller i profetiske evner, og anser dem for et sidespor, ${ }^{2.3}$ da de er fænomener og ikke væren; mystikeren vil alene den absolutte ontologiske enhed med Det Ene Absolutte, Gud.

Sammenlign ovenstående citat med eksempelvis Johannes 4,23-24, hvor Kristus siger:

»Men den tid kommer, ja, er allerede inde, da de sande tilbedere skal tilbede ( $\pi \rho \circ \sigma \kappa v v \eta ́ \sigma o v \sigma ı v$, egl. hylde, overgive sig til) Faderen i ånd [pneumati] og sandhed; thi det er sådanne tilbedere, Faderen søger. Gud er ånd [pneuma] og de, som tilbeder ham, bør tilbede i ånd [pneumati] og sandhed.«

Pneuma angives her som det, der på én gang er Gud og er det, hvori den hengivne skal forholde sig til Gud. Det er essentielt at bemærke Kristi pointe: at Gud ikke skal findes i det, der er udtryk for pneuma, d.v.s. ord, handlinger, m.v., men i selve pneuma, og at pneuma og Gud er ét. Derfor: Man skal overgive sig til Gud i Guds eget væsen, som er menneskets eget væsen, og det væsen er i sig selv overgivelsen og ét med Gud. Eller som Eckhart udtrykker det: »Da mennesker endnu stod i Guds evige væren, eksisterede der ikke andet $\mathrm{i}$ dem. Hvad der eksisterede i dem, var dem selv.« Ovenstående bibelpassage udtrykker kernen i den kristne mystik og forklarer, hvorfor Kabbalah aldrig kan vare mystik. 
Talmud og Midrash er en del af alle tro jøders hverdag og er ikke esoteriske på nogen måde: deres praksis består af læsning og metalæsning af teksten. Kabbalah adskiller sig herfra i to henseender: 1) graden af intensitet i hvilken man fordyber sig $\mathbf{i}$ ord, og hvilke ord der prioriteres for meditation og $\mathbf{i}$ hvilken orden, 2) ved at angive specifikke ruter for fremskridtet af ens indre åndelige praksis, der baserer sig på at anråbe og indkalde kræfter eller ảndevæsner (f.eks. et engleviesen, en maggid), der kan udrette det, man ikke selv evner, f.eks. at etablere et møde med Gud, eller det mere prosaiske: at beskytte én på rejser, fange fisk, give en fysisk kontakt med en begreret kvinde, mv ${ }^{24}$ altså ren magi og okkultisme.

Kabbalah er i modsatning til den transcenderen ud over grænsen mellem selvets væren og Guds væren, der udgør mystikkens gebet. I ekstreme tilfælde synes det dog at kabbalisten giver udtryk for en enhed med Gud, der minder om den ontologiske enhed, mystikeren søger. Rabbi Joseph Caro (1488-1575), der forfattede Sulchan Aruch (Jødernes lov-kodeks) og stiftede et talmudisk akademi i Salonica 1534, skrev et kabbalistisk vark, Maggid Mesharim (en maggid er en art engel; skriften er meddelelser fra denne maggid), i hvilket vi finder følgende:

»Dette er Enhedens mysterium, ved hvilket en person i bogstavelig forstand gør sig til ét med sin Skaber. Sj:elen knytter sig så meget til Ham, og bliver i den grad ét med Ham, at kroppen bogstavelig talt bliver en residens for Guds nærvær. ${ }^{25}$

Vi kan ikke læe denne passage uden at huske på læren om ispaklaria: at gudsoplevelsen aldrig kan være andet end medieret ved et højere væsen. Enhedsforestillingen minder dog essentielt om kristne mystikere som Eckhart og Symeon (949-1022) i en sådan grad, at vi kan undre os over, om ikke en indflydelse fra den kristne mystik og Plotin har sneget sig ind i rabbinsk tæenkning på dette tidspunkt.

Meister Eckhart har, som det er sædvane i mystikken, opbygget hele sin lære som vidnesbyrd om, hvad han selv angiveligt har realiseret og i det lys udlægger han skriften. Det er indlysende en ganske anden vinkel end rabbinerens, der bruger udlægning af skriften som et middel og en vej og anser forståeIsen af skriften som målet. Mystikken erklærer, at den ontologiske enhed af Gud og menneske er ikke blot mulig og realisérbar, men evigt aktuel og en faktuel realitet, som vi i almindelighed dog er ude af stand til at begribe. ${ }^{26}$

Rabbineren søger ikke enhed med Gud i ontologisk forstand. Heller ikke er kærlighedsforholdet mellem Gud og menneske et forhold mellem Gud og det individuelle menneske, men mellem Gud og et helt folk: Israel. Den kristne mystik er orienteret om forholdet mellem Gud og individ, derved bliver der plads til en ontologisk enhed mellem den enkelte og Gud. ${ }^{27}$ Rabbineren stude- 
rer Torah for at bistå Gud i hans skabelsesværk og således hjæelpe verden mod den fuldkommenhed, som Gud fører sin skabelse hen imod. Rabbineren sæetter teksten over alt:

»Den, der gár ud ad en vej og repeterer [sin Torah-tradition], men afbryder sin repetition og siger: 'hvor er dét træ smukt. Hvor er dén pløjede mark skøn!' Skrifterne ser pả det, som var han skyldig i en dødssynd.« (Rabbi Simeon, Mishnah: Abot 3:7).

Ordet går forud for ikke blot tingen, men også vores varen. Rabbineren er săledes mere »kryptogrammatolog« end mystiker, for han søger at nærme sig enhed med et betydningsindhold, der kan udledes af et skriftkompleks gennem kryptografiske metoder.

Rabbineren vil mene, at ens væren kommer af ordet. Mystikeren derimod pointerer, at man transcenderer hele det felt af bevidstheden, hvori forståelse, tekst o.s.v. gør sig gæeldende. Den absolutte indsigt, som selvfølgelig falder sammen med enhed med Gud, har som forudsietning, at man transcenderer sproget, skriften, og erkender, at man ontologisk er ét med Det Ene, Gud.

For mystikeren er det således utrenkeligt at definere mennesket som en skrift-automaton og hæevde, at alt er »écriture«. Den kristne mystiker vil overskride alt og blive genforenet med Gud som Kristus er ét med Gud, ${ }^{2 *}$ rabbineren vil rầde bod på sin manglende viden og forstå Guds plan.

Mystikeren vil derimod mene, at écriture, og identifikation dermed, er grundelementet $\mathrm{i}$ menneskets åndelige ignorans. Som William James bemærker: »Henrykkelsens uudsigelighed er en grundtone i al mystik. [.. Det er en fortiersket ting indenfor metafysikken, at guddommelig indsigt ikke kan viere diskursiv, men må viere intuitiv $\ll{ }^{29}$ Den kristne mystiker, som det er typisk for mystikken, mener, at Gud er immanent i ham selv ${ }^{30}$ omend skjult af hans egen umiddelbare synd og den middelbare synd, der ligger i hans viesen (»arve«-synd). For så vidt er synd, for mystikeren, ikke egentlig brud på moralkodeks (moral for dets egen skyld), men slet og ret det $i$ hans viesen, der adskiller ham, og holder ham adskilt, fra enhed med Gud.

Ofte siger man om kabbalisten, at han er mystiker, men det er begrebsforvirring; »mystik « (og »mysticisme «) er et graco-kristent begreb, der er aldeles uforeneligt med rabbinsk opfattelse. Rabbinerens metode er ikke mystik og hans mål er ikke mystikerens mål. Mystik er derimod, om noget, indbegrebet af ontoteologi: at ville erkende sin Guddommelige Væren. Rabbineren er i grunden kryptosemantiker, mystikeren er slet og ret mystiker, den græco-kristne tæuker er ontoteolog. 


\section{I begyndelsen var ordet - eller: Det er Gud, der taler}

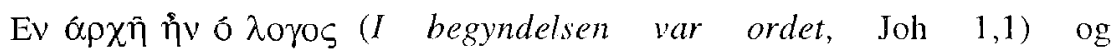

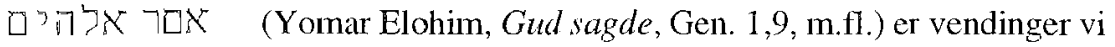
nødvendigvis må granske lidt; desuden må vi granske betydningen af logos og det hebræiske ord for »ord «: 77 (Dãvãr, eller dãh-bãhr).

Logos oversættes med »ordet«, hvilket er mangelfuldt, bl.a. fordi logos ikke betyder et ord i grammatikalsk forstand, men rettere det ytrede ords betydningsindhold. Logos henvender sig til indholdssiden. Det kan betegne et koncept eller en mental forestilling; i stoisk forstand en hypostatisk urfornuft eller en evig altgennerntrængende visdomsstruktur, der organiserer hele skabelsen. At der i Johannes ikke er tale om »dengang i begyndelsen «, men tale om et tidløst evigt nu, tydeliggøres af at verbet ๆొv, (der klodset oversættes »var«) betegner et tidløst nu og altså ikke noget fortidigt. Desuden af »arché«, der ganske vist kan referere til »første gang«, men rettere (uomtvisteligt gør det sammen med $\eta ๊ v$ ) betegner tidløst ophav eller urprincip; arché kan også betyde фverste autoritet, magistrat. Johannes formår således at tage græsk (stoisk) filosofi og rabbinsk teologi og føre dem sammen i en art »visdoms-ontologi «, hvor ordet ikke lengere refererer til en skabelsesplan (Torah), som Gud følger, og logos ikke længere til en bevidstløs urkraft eller arkelogik, men til en hypostatisk visdoms-væren, et alvidende (Guds) væsen, der er inkarneret i Kristus. Dermed er indført at visdom ikke er at finde i skrift, men i ontologi, og at den visdom ikke er død tænkning, men bevidst og udødelig Væren. At erkende denne Væren som sig selv, ens egen væren, er mystikerens projekt.

Det hebraiske ord for »ord « er dãvãr, hvilket bedst svarer til det graske »rhema« (der dels betegner det ytrede ords lydlige form og siden det, denne udsigelse udsiger; rhema går altså fra udtryk til indhold, modsat logos). Dãvãr forekommer ikke i forbindelse med Genesis, det gør derimod $\square$ I (yomar), der oversættes »sagde«. Yomar betegner imidlertid foruden at ytre også at ville eller at kommandere. Yomar i Genesis har da den dobbelthed, at skabelsen kom af en Guddommelig viljesakt, der udfoldede sig i sprog og siden blev de konkrete ting.

Dãvãr har en dobbeltbetydning: dels ords meningsindhold (som rhema), dels ting og genstande, men også: sager, der skal udføres eller er udført (f.eks. Solomons gerninger). Det er således svært at skille yomar fra dãvãr, idet udsigelsen af et navn skaber tingen; navn og ting er en udelelig enhed. Vi finder hos kabbalisterne, at udsigelse af ord har en magisk kraft, der svarer til skaberkraften: at den korrekte udsigelse, udtale, af ord også er udsigelse, eller hidkaldelse, af de ting, de betegner - hvilket er en almindelig grundopfattelse i magi. Ord og ting er således uløseligt forbundet i rabbinsk tænkning, til forskel fra 
græsk tænkning, der skiller dem ad (onoma, navn, ord, er arbitrær og referentiel, i bedste fald en lydlig efterligning). For kabbalisten forholder det sig sådan, at siden alting er skabt af sproget, så vil kendskab til det sprog give ham indsigt $\mathrm{i}$ alt.

For rabbineren er ordet tingen, virkeligheden, i sin mest essentielle form; for Derrida er ordet kendetegnet ved en dobbelthed, différance, (mere end Saussures binaritet), dvs. både en 'forskellig fra' og en holden hen. Vi kan sige, at for kabbalisten er sproget hypostatisk; for dekonstruktivisten en hyperstase i hvilket vor erkendelse er fanget. Umiddelbart kan de to betragtninger ligne hinanden gevaldigt, idet begge udelukker ontologi og mystik; men der er magi til forskel.

\section{Oh, noma!}

Ordet er for rabbineren ikke arbitræert, men guddommeligt. Hos Platon og Aristoteles er ordet (onoma) blot et arbitrært navn, d.v.s. noget, der ikke indeholder genstandens ontologiske sandhed, men blot henviser dertil. Aristoteles fastslăr $\mathrm{i} »$ De Interpretatione «: »Et navn er en udtalt lyd, der får sin mening ved konvention $\ll .{ }^{31}$ Ordene er tegn, der ikke henviser til ting rent ontologisk, men til tingenes fremtræedelsesform. Ordet i sig selv er altså uden sandhed, spørgsmålet sand/falsk vedrører derfor ikke ord, men alene idéer. Sproget er desuden mimetisk; $\mathbf{i} \gg$ Kratylos « fastslår Platon, at »navnet er stemmens imitation af et givet objekt, og at man siges at have givet et objekt navn, når man imiterer objektet med stemmen $«{ }^{32} \mathrm{Og}$ videre i samme: »Han, der forfølger navne i sin søgen efter ting, og analyserer deres mening, udsætter sig for vildfarelse. $\ll^{33} » \ldots$ viden om tingene kan ikke udledes af deres navne. $\ll^{34}$. Dette er i modstrid med rabbinsk opfattelse.

De kristne allierede sig tidligt med græsk filosofi og Plotin og skubbede tydeligvis deres teologiske rødder i rabbinsk hermeneutik ud. Dette har været en gradvis proces, der ikke lader sig fæstne til nogen snæver periode eller til nogen person. Allerede i Paulus' breve finder vi opgøret med jødisk verdenssyn.

Hos Pseudo-Dionysius finder vi mystiske betragtninger, der har præget den kristne mystik stærkt fra den tidligste middelalder. I $»$ The Divine Names $\aleph^{3.5}$ opremser og forklarer han Guds navne (fra Biblen) og opmuntrer til refleksion derover; dette princip er selvfølgelig temmelig rabbinsk og udgør det centrale i så megen jødisk meditationspraksis. Skal vi datere skifttet fra navn til væren, må det blive med dette skrift. Allerede i det 1 . århundrede finder vi en hel tal- 
mudisk skole baseret på grafocentrisk meditation. Men han skriver også dette meget u-jødiske i »The Divines Names« (VII,3):

»Dette er den mest guddommelige indsigt om Gud: at han kendes gennem vidensaflægning, i overensstemmelse med den enhed, der overskrider forståelsen, når forståelsen trækker sig bort fra alt og forlader sig selv.«

Vægten ligger således på transcendens, endda selvtranscendens. At bemærke forståelsens inferiøritet overfor gudserkendelse i en afhandling om Guds navne og deres funktion i spirituel praksis er et anslag mod rabbinsk opfattelse af samme. Den centrale praksis for den rabbinske mystik er som næunt refleksion over Guds navn og bogstavet, men rabbineren søger ikke ud over forståelsen af ordet ej heller ud over selve forståelsesapparatet, men tværtom ind $\mathbf{i}$ ordet og forståelsen deraf; for rabbineren er ordet det første. Rabbinerens teocentricitet er således en grafocentricitet, mens den kristne teocentricitet er ontocentrisk. Rabbineren ønsker ikke at komme bag om viden, som den kristne mystiker vil, men vidensophobning - $\mathrm{i}$ en sådan grad, at der til hver enkelt ord i det gamle testamente principielt kan udvirkes uendelig mange endeløse afhandlinger. Til forskel fra rabbineren, der vil mene at gudserkendelse er uadskillelig fra navnenes (og ordenes) fonetiske og grafiske fremtræden, og altså insisterer på at »ordet er virkeligheden i dens mest koncentrerede, kompakte, essentielle form $\ll^{36}$, ser vi hos Dionysius, at navnet henviser til en kvalitet udenfor sig selv, der er transcendent. Navnet har således skiftet status fra absolut (guddommeligt) til relativ (i den forstand at det er en semantisk funktion: en arbitrær signifikator).

Johannesevangeliet er loyalt mod rabbinsk metafysik, når det erklarer »I begyndelsen var Ordet «; men straks efter erklærer Johannes, at Ordet er inkarneret i, og er, Kristus. Gud er således ikke liengere en fraværende udsiger men hellig ånd inkarneret $\mathrm{i}$ Jesus Kristus; Det gamle testamentes ord bliver derved vidnesbyrd om ånden i stedet for det, hvori ånden er immanent. Erkendelsen af Gud ligger derfor, for de kristne, heller ikke længere i ordet, men i ånden: det er Helligånden, der vejleder den kristne. ${ }^{37}$ I sig selv er ordet, for den kristne, altså ikke andet end et konventionelt sprogtegn, en signifiant, der henviser til Gud: den yderste signifié. Allerede for de tidligste, paulinske kristne var det gamle testamentes ord ikke meget mere end profetier om Kristus - og med Kristi inkarnation i Jesus var det gamle testamente fuldbyrdet og dets ord forvandlet til blot skrevne ord: rabbinernes unævnelige, navnløse Gud var pludselig fysisk nærværende og dermed distinkt og væsensforskellig fra teksten. Ordet var nu, med andre ord, ikke læangere Gud, men et vidnesbyrd om Guds 
komme. Ordet blev derved forvandlet fra at rumme Guds unævnelige og uafgrenselige nendelighed, til at være referentiel - ikke henvisende tilbage til et forgangent skabelsesøjeblik og en fraværende Gud, men fremad til en begivenhed fikseret i fremtiden. Når de kristne fastholdt, at denne fremtidige begivenhed, som teksten peger frem imod, var indtrådt, să reducerede de selvfølgelig tekstens status. Kristus er således det primere, hvorfor hans udsagn (i evangelierne) bliver primærtekst; Det ganle testamente sekundirtekst. I det øjeblik et sådant hierarki indstiftes i forhold til teksten kan man ikke opretholde forestillingen om tekstens guddommelige eviggyldighed.

De kristne placerede teksten i et verdenssyn styret af kronologisk årsags-virkningssammenhrenge; den blev narrativ og profetisk, men ikke liengere autoritativ. Rabbinernes tekstopfattelse, selv om deres Mosebøger angiveligt er en historisk beretning, binder ikke dens betydningsindhold $i$ tid, den er til enhver tid det, livet formes efter. For dem har teksten en tredobbelt status: både en historisk narrativ, en ahistorisk lovformelig og en metafysisk guddommelig (planen for Guds skabelsesverk) - og de udgør vel at mærke (for rabbineren) ingen modsigelse.

$\gg$ Den primære drivkraft i Midrash er udad, imod den ydre verden, mod at fo̊ Torah til at omslutte enhver mulig begivenhed i den verden. Dens bestrabelser er altid mod at opretholde den hellige teksts relevans - dens narrative dele såvel som dens lovmæssige - i de forandrede forhold gennem Israels historie. ${ }^{38}$

Dette kan selvfølgelig kun lade sig gøre ud fra den opfattelse, at teksten i sin guddommelighed er hævet over tid og sted. Dens hermeneutik kan derfor kun vanskeligt være bundet af de grænser, den aristoteliske logik, og den derpå baserede vestlige hermeneutik, underlæegges. Når skabelsen udgår af et ord, der pludselig prentes på intet, og udgår af det ords lige så pludselige udfoldelse i alfabet, så kan vi ikke langere opretholde forestillingen om Absolut Væren og arché eller for den sags skyld axiomer. Når der ikke læangere er axiomer at basere sig på og arché at kategorisere efter, så kan en logik som den græco-kristne ikke længere fungere. Man må da benytte en anden praksis for tæenkningen. En sådan er midrash og dens hermeneutiske principper. Den aristoteliske logik siger, at skabelsen er styret af lovmæssigheder, den rabbinske siger, at den er styret af Gud i overensstemelse med Torah og at lovene er udtrykt af Gud i Torah. 


\section{Logik eller midrash}

Den vestlige logiks grundsten er syllogismen. Syllogismen athænger af, at der en subjektspradikatrelation mellem to emner, hvor man søger at vise, at det underordnede, subjektet, er indeholdt i det overordnede pradikat. Dette ophøjer imidlertid subjektspriedikatrelationen til fiellesnævner for alle sande domme og al sand argumentation. Aristoteles siger derved indirekte, at følgeslutninger baseret på andre former for relation end den pridikative, er uvæesentlige og dermed ugyldige.

Sandheden om subjektet menes med andre ord at udgøres af et præedikat. Den logiske dom afdækker, eller sietter, altså ikke et nyt koncept, der står over subjektet, men lader subjektet passere over i pradikatet, hvorved subjektet ontologisk glider bort til fordel for en predikativ betegnelse. Dette er ikke nogen ny kritik. Allerede Hegel ytrede den - og han bemarkede endvidere, at predikatet spierrer for tankens videre bevegelse, samt at logiske domme baseret på subjektspradikatrelation ophæver sig selv: al filosofi reducerer derved sig selv til at vare pradikativ. ${ }^{39}$ En kompromisløs men svært gendrivelig kritik.

Aristoteles gik fra Platons søgen efter tingenes ontologi til en klassifikation efter præedikative kategorier: kvantitet, kvalitet, osv. ${ }^{40}$ Derved flyttede han erkendelsen fra spørgsmålet om et givet subjekts varen til spørgsmålet om, hvorvidt subjek tet kunne siges at være eller ikke være det ene eller det andet. Aristotelisk logik beskieftiger sig således med at beskrive relationer mellem de prædikater, dens domme udgøres af; det er et kritisk punkt, for den tager derved ikke stilling til relationerne mellem dommene i sig selv - faktisk beskæftiger den sig slet ikke dermed. ${ }^{11}$

Aristoteles er, trods andre uenigheder, enig med Platon om, at diskurs og væren er to væsensforskellige områder. Denne ontọlogiske skelnen mellem vieren og diskurs er vigtig, da den er udgangspunktet for den vestlige metafysik og samtidig er i modsatning til rabbinernes opfattelse: at vieren og diskurs er ét.

Aristoteles og Platon er enige om, at man for at nå sand erkendelse, d.v.s. erkende ousia, tingen i sig selv, må bevæge sig ud over ordet, onoma. Ordene kan dog udtrykke den begribelige struktur af en ting, dens logos, eller fremsæette definitioner, hvilket også er logos. Logos og ousia kan aldrig falde sammen: det er ousia, vi vil tale om, men logos vi står med. Ousia kan selvfølgelig aldrig vare et prædikat. Alligevel må samme antikke logik i praksis håndtere sandheden om tingene, dvs. ousia, med prædikater.

Logikken begransede sig fra og med antikken til de bivalente udsagn (sand/falsk: enten $P$ eller non-P). Logikkens første princip blev, at intet kunne 
være både $\mathbf{P}$ og non-P (det såkaldte »kontradiktionsprincip $«$ ). Da metaforen gør vold på dette princip, blev metaforens sprogbrug - retorik og poesi - bandlyst fra videnskaben. Freud har siden argumenteret for, at underbevidstheden ikke overholder denne kontradiktionslov, men uden videre lader ting være både-og. Rabbinsk logik har ikke kategoritænkningens syllogistiske sand/falsk som grundsten, men derimod som navnt: »hvis ..., hvor meget mere sikkert er det sai ikke at ... «

Det væsentlige er nu for os at forstå, at deres tænkning benytter sig af en art semantisk translokation eller polylokation, til forskel fra logikkens prædikative kategorier. Semantisk translokation minder selvfølgelig påfăldende om meta-phérein, princippet i metaforer og metonymi.

\section{Problemet metafor.}

\section{Skriften som metafor for Sandheden}

I sig selv er Aristoteles' logisk gyldige udsagn metaforiske, for de lader subjektet forsvinde i prædikatet - de overser, at prædikatet ikke er lig subjektet selv, men i alle tilfælde vil vare en metafor for subjektet. ${ }^{42}$

Derrida pointerer, at den vestlige (i.e. Aristotelisk baserede) metafysiks problem er, at den på den ene side afviser metaforens gyldighed, men på den anden side glemmer, at hele dens grundlag er metaforisk: enhver abstraktion er i sit væsen en metafor. Han skriver, at den vestlige metafysik aldrig har gjort sig klart, at dens grundlæggende koncepter (theoria, eidos, logos, arché, etc.) er metaforer.$^{43}$ Desuden, at $\gg$ siden dens intrumenter tilh ører dens eget område, er filosofi ude af stand til at beherske sin egen tropologi og metaforik. Den kan alene se sine metaforer ud fra et blindt punkt eller en central døvhed $\ll{ }^{44} \mathrm{Og}$ han konkluderer: »Metaforik bærer altid sin død i sig selv. Og denne død er, på det bestemteste, også filosofiens død. « ${ }^{45}$

Når man overser, at pradikatet blot er en metafor for tingen, så sker der det, at man forveksler analogi med participation, eller i værste fald: identitet. Aristoteles overså (eller undveg) denne knibe ved at definere metaforen som overførsel af navneord fra et objekt til et andet. ${ }^{46}$ At prædikatet, på samme måde som navneordsmetaforen, overfører mening fra en syntaktisk enhed til en anden, undgik hans opmerksomhed. Egentlig udgik hans ovevejelser fra hans substantiviske kategoritænkning: »Metafor er det at bruge en tings navn på noget andet; overførslen kan være enten fra slægt til art, art til slægt, eller fra art til art eller også være et spørgsmål analogi. «47

Derrida vil gerne, at vi flytter opmærksomheden fra sprogets »statisk signifikante « elementer (navneord og prædikater) til dem, der betegner relation, 
d.v.s. verber, konjunktioner, endelser, mv. Hans projekt er således, at bringe opmærksomheden til sprogets egen indre logik, - for derigennem at komme til klarhed over de tænkningens principper, der ligger bagved hele det konceptuelle apparat, hvormed vi i snart 2500 år har iiæermet os ting og tekster. Om dette projekt er han ikke alene: det deles feks. også af Barthes, Freud, Ricoeur, Gadamer og Lévi-Strauss.

Ricaur kalder metaforen for en »splittet reference«, ved det at »at være som ...« på én gang betyder »at være lig ...« og »at være forskellig fra ....««8 Metaforens særlige væsen er altså ikke overførsel af et substantiv fra et objekt til et andet, men: sammenføring (»lig «) af forskelle (»forskellig fra«). En sådan metaforik arbejder psyken med. Freud klarlagde, at forløbsmassig sammenstilling i drømme afslører semantisk kobling mellem elementer og dermed overføring af betydningsindhold fra det ene element til det andet. Rabbinsk hermeneutik har som nævnt et princip kaldet semukhin, der tillægger sammenstilling en semantisk funktion.

Den vestlige logik vil udlede sin forståelse af det konkrete fra en abstrakt regel, den rabbinske omvendt. Abstraktionen løsriver tegnet fra dets indhold og gør tegnet og sproget arbitrært, for rabbinerne derimod bliver sproget ikke et spørgsmål om repræesentation, men om at gribe virkeligheden og dens love; dette betyder, at for rabbineren er sprogtegnet metonymisk, i modsætning til i vestlig logik, hvor det er metaforisk. Den rabbinske metonymi kommer af et fletværk af tekst, hvor den vestlige abstraktions metaforik kommer af en forestilling om ækvivalens mellem begrebets abstrakte indhold og tingen, begrebet henviser til.

Men lukker jøderne sig, som dekonstruktivisterne, ikke inde i teksten ved at niegte, at en metaforisk overensstemmelse mellem predikat og objekt er en særegen betinget overensstemmelse og ikke en radikal uoverensstemmelse? Deres principper synes at underordne abstraktion det konkrete. Men når det konkrete $\mathrm{i}$ alle fald er tekst, og studiet af tekst står over beskrivelse og analyse af den konkrete natur, er så ikke deres konkretioner pseudokonkretioner?

\section{»Rabbi« Freuds psykokabbalisme}

»I drømmetydningen har vi på ingen måde set det som mindre vigtigt, $\mathbf{i}$ hvilke former ordene lægges frem, selv de mindste nuancer. /.../ Kort sagt: Vi har behandlet det, som andre f $\varnothing \mathbf{r}$ os har betragtet som arbitrær improvisation, som Den Hellige Skrift. «"

$»$ En drøm, der ikke er tolket, er som et bogstav, der ikke er læst. «" 
De hermeneutiske principper, som Freud tager i brug over for drømme, er så lig de rabbinske, at man ikke blot kan tale om at Freud flyttede Den Hellige Skrift over i subjektet, men også om at han flyttede Jahve over i subjektets dybeste kroge og kabbalisten ind $i$ analytikeren.

Med andre ord synes han at se drømmen som urudsigelse (Torah) og det ubevidste som det fraværende nærvær ( $\gg$ Jahve«, der er, hvad han er), der på dunkel vis ytrer sig i og som psykens materiale. Og ydermere, ganske som Jahve relaterer til sin skabelse og studerer Torah og derudfra fortsat skaber verden, sai relaterer det ubevidste fortsat til verden og sin egen diskurs og skaber derudfra fortsat verden. Drømmeteksten, der således bærer vidnesbyrd om det ubevidste, synes ikke alene uadskillelig fra subjektet, men også ét med subjektet. En identitet, der ikke er entydig men polysemisk, og som kun kan afdiekkes ud fra den grundopfattelse, at enkeltdelen, forstået ud fra de tekstdele, den kan relateres til, rummer udsigelse af en anden orden. Drømmeteksten er săledes det navnlø̧se (og hér således det fravierende og uopnåelige, som Jahve) subjekts metonymi. Tekstens udtryk for subjektet kan derfor kun afdakkes, hvis man afkoder teksten efter korrekte hermeneutiske principper, men det bliver kun tilnærmelsesvis, aldrig endeligt. Lacan tager ideen om bevidsthedstekst til sin konsekvens og beskriver psyken som en tekst. ${ }^{51}$

At Freud har varet bekendt med Midrash og Talmud er der ingen tvivl om: han er, som alle andre jøder indenfor traditionen, vokset op med den fra han lå i vuggen. De 13 middot er en del af den daglige rituelle andagt, og Freuds forxeldre var engagerede jøder. ${ }^{52}$ Ser vi Freuds opfattelse af drømmen som en tekstopfattelse (jvf. hans analogi mellem drøm og »Den Hellige Skrift «), så adskiller den sig vesentligt fra den traditionelle vestlige opfattelse af tekst, men falder sammen med den rabbinske. For Freud og rabbinerne befinder tekstens betydningsindhold sig uden for et lineiert tid/rum kontinuum; fortidige hændelser indskrevet i teksten kan være afgørende for, hvordan livet/skabelsen udformes i dag eller i fremtiden. Nedskreven fortid reaktualiseres ved en given situation, betydningsindholdet kan forskydes (semantisk translokeres) ved samspil med andre tekstdele, og afføde nye love for livet og tilvarelsen. Hver enkelt del står i drømmen ikke blot i forhold til enhver anden del, men er et aspekt deraf; ydermere er lieseren (analytikerens) udlegning et aspekt af drømmeteksten i og med at han oplever og arbejder med den med henblik på at forstả den og samskrive den med nutiden. Drømmeteksten analyseres ud fra drømmeteksten selv og med dens eget materiale ud fra dens egen logik; ganske som Torah og som rabbinernes hermeneutiske principper er uddraget af teksten selv. 
Psykoanalyse er, set med den vestlige videnskabstraditions øjne, en hybrid af human- og naturvidenskab. Den forbinder semi-mekaniske systemer som forskydning, projektion, substitution, o.s.v. med hermeneutiske problemfelter să som: åbenbar og skjult mening, symptom og fantasi m.v. Psykoanalysens metode er en søgen efter specifikke mekanismer gennem tolkning af metonymiske forhold, altid ud fra det forhåndenverende materiale.

Freud skriver, at hver eneste tankerække nærmest uundgåeligt er ledsaget af sin modsætning og knyttet dertil ved antitetisk association. Hver enkelt del af drømmens komplekse struktur er forbundet med hinanden ved en mangfoldighed af logiske relationer. De kan være forgrund og baggrund, digressioner og illustrationer, udgøre betingelser for hinanden eller retfærdiggøre domme eller udgøre modargumenter. ${ }^{53}$ Dette svarer til rabbinerens opfattelse af teksten.

Freud analyserer sin egen tilsyneladende meningsløse bemærkning, at selv om hans Drømmetydning havde 2.467 fejl, så ville han ikke lave yderligere endringer den. Han deler tallet op i 24 og 67 og finder at 24 repræsenterer hans 24 års fødselsdag og dermed hans voksenalder; dernæst lægger han 24 til sin nuværende alder, 43, og finder at det giver 67; deraf konkluderer han, at indfaldet 2.467 betyder, at han nærer $\emptyset$ nsket om at kunne arbejde $i$ yderligere 24 år på sit vaerk. Det er ren gematria. Ganske vist er 67-24=43, men selv om det er hans nuvæerende alder, så har det ikke forklaret 24 og 67 uden ved det, at siden deres differens, 43 , giver samme resultat som hans nuvarende alder, så er 67 og 24 nok også betegnelser for alder! ${ }^{54}$

På samme måde optræeder semukhin i Freuds drømmetydnings-metodik, når han tolker, at affekt fra et drømmeelement $\mathrm{i}$ virkeligheden hører til et andet element, der forekommer (uden affekt) i tilknytning dertil. Semukhin er den rabbinske metodik til at forklare, hvorfor to sidestillede passager, der ikke synes at have noget fælles indhold eller forløb, er sidestillede. Rabbineren forklare at der må vere en mening med sammenstillingen, siden sammenstillingen er af guddonmeligt ophav; Freud siger, at der må være en mening, siden sammenstillingens ophav er det ubevidste.

Hans metodik inddrager notarikon, når han bryder ord op i enkeltelementer og lader analysen tage udgangspunkt $\mathrm{i}$ de udragne elementer frem for det oprindelige ord (f.eks. bliver »norekdalsk « til Nora og Ekdal, »Maistollmutz« analyseres til enkeltdelene: mais, toll, mannstol og Olmutz ${ }^{55}$ ).

Ens lydlig vardi menes at betyde ens semantisk indhold (»rechts« (til højre) betyder på den måde rigtig, og gennem antitese betyder venstre så forkert, og alt efter en moralske habitus: »homoseksualitet, incest, perversion $\aleph^{56}$ ). I det hele taget sammentrakkes ligheder til en enhed sådan at kun den ene del fremstilles, mens den anden del er underforstået. ${ }^{57}$ 
Freud skriver: »Det er ved tydningen af hvert drømmeelement sædvanligvis tvivlsomt, om det a) skal tages i positiv eller negativ betydning (modsatningsrelation), b) skal tydes historisk (som reminiscens), c) skal tydes symbolsk, eller om d) dets tolkning skal udgå fra ordlyden. ${ }^{5 x}$

Flere lighedsprincipper kunne påpeges, men ovenstående synes tilstrækkelige til at anskueligg øre overensstemmelsen.

Vi kan nu fristes til at stille det indlysende spørgsmål: Er da Freuds psykoanalytiske praksis blot en forskydning af hans fortrangte jødiske barndom? Og er dermed psykoanalysens hermeneutiske metode blot en forskydning af rabbinsk hermeneutik så psykoanalyse i virkeligheden er psykologiseret kabbalisme? Det er der andre, der har overvejet.

Freud var hele livet splittet mellem sine jødiske rødder, som han følte, at han havde forrådt til fordel for den vestlige civilisation og den vestlige akademiske verden, som han blev holdt ude af, men desperat ville anerkendes af. En kritisk lesning af Freuds: The Origins of P sychoanalysis tydeligg $\varnothing \mathrm{r}$ Freuds ambivalens med hensyn til sin baggrund. F.eks hevdede Freud, at han ikke læengere kunne læse hebraisk, men alligevel var Freud så forbundet med sin lærer i hebraisk, at han navngav sin egen datter, Sophie, efter dennes niece. I hvertfald må man ud fra Freuds eget system mene, at det er udtryk for en stark affekt, der forskydes fra ét objekt til et andet. Og Freud modtager af sin fader, på sin 35 års fødselsdag, en bibel med hebraisk indskrift, hvilket synes besynderligt, hvis han ikke kunne læse hebraisk. Flere sådanne eksempler på, at han var mere rabbinsk, end han indrømmede, kan findes. ${ }^{59}$

David Bakan har påpeget de strukturelle ligheder mellem rabbinsk exegese og drømmetydningens hermeneutiske metode. ${ }^{61}$ Han placerer Freuds metoder indenfor den kabbalistiske tradition og konkluderer kompromisløst, at psykoanalyse er sekulariseret kabbalah.

Han fastholder endvidere, at Freud bevidst har tilsløret sin sekulariserede kabbalistiske metode for ikke yderligere at kompromitteres i forhold til den akademiske verden, han kæmpede så hårdt for at få anerkendelse af. Bakan javnfører i nogen grad kabbalah med midrash - hvilket dog ikke er noget problem i vores sammenhang, da pointen deraf kun understreges: at hermeneutikken i Freuds psykoanalyse er fundamentalt rabbinsk og hører under rabbinernes exegetiske tradition: midrash.

Vi har ingen intentioner om hér at svare på spørgsmålet om, hvorvidt de mekanismer, Freud beskrev vedrørende det ubevidste, diekkende beskriver det ubevidstes funktionsmåde, eller de er udtryk for, at det system, han iagttog det ubevidste gennem, alene tillod ham at iagtage det ubevidstes mekanismer $\mathbf{i}$ udvalg. Eller hans fortolkning måske endda indebar en omskrivning af en anden ubevidsthedens »logik «. Ej heller kan det afgøres, hvorvidt Freuds udlag- 
ning af drømmens logik (bevidst eller ubevidst) er baseret på rabbinsk logik, eller rabbinsk logik intuitivt er baseret på drømmens logik. Dette sidste kan være en uhyre vasentlig pointe, for historisk set udspringer rabbinsk hermeneutik af drømmetydning. David Stern skriver:

\begin{abstract}
»Rabbinerne var istand til at behandle Torah'ens textualitet på netop den måde, de gjorde, fordi der allerede eksisterede et forbillede for deres synspunkter i den måde, man i oldtiden tolkede drømme - som budskaber sendt fra himlen, orakuløse i deres indhold, gådefulde i form og derfor med et tvingende behov for at afkodes. Det, rabbinsk exegese opnåede, var at tilpasse drømmetydning til de nye behov for et system, der kunne tolke den hellige tekst. $\ll^{61}$
\end{abstract}

Nu skal det selvfølgelig erindres, at drømmetydning dengang ikke var, hvad det er idag. Men rabbinernes hermeneutik kan have udviklet sig mod en mere præcis refleksion over, hvordan underbevidstheden investerer mening i diverse sager. Overensstemmelserne kan ihvertfald pege på det mulige, at den rabbinske logik baserer sig på en underbevidsthedens logik, hvor den græco-kristne baserer sig på en bevidsthedens logik. Men Freuds drømmetydning bygger på mange andres iagtagelser, og dens fremstillede principper for drømmeelementers semantiske translokation har vist sig levedygtige i snart hundrede år, så det synes ikke rimeligt at tilskrive de beskrevne mekanismer Freud alene. Men hvordan han systematiserede dem og kom bag om dem til en samlende teori om psykens struktur: det udgør et helt andet diskutabelt område og befinder sig på et andet fortolkningsniveau end den elementære indsamling af materiale, som registrering af drømmeelementernes semantiske investeringer udgør. Der kan derfor, uanset hvad der iøvrigt kan siges om forholdet mellem Freud og midrash og kvaliteten af hans psykologiske model, argumenteres til forsvar for Freuds »psykologiserede midrash $\ll$, at der i Freuds arbejde synes at være en bekraftelse af (ihvertfald dele af) rabbinsk hermeneutisk metode på videnskabelig grund.

\title{
Barthes og écriture-fetichismen
}

For en tekstteoretiker og kritiker er følgende bemærkning tankevækkende:

»At fortolke en tekst er ikke at give den en mening (mere eller mindre rimeligt, mere eller mindre frit), men derimod at værdsætte den pluralitet, den udgøres af, « ${ }^{62}$ 
Barthes vil lade læsningen være et metonymisk arbejde med teksten. Han vil dekonstruere teksten, sådan at forstå, at han ved at fragmentere den, bore ind i dens forlegenheder (aporier) og digressioner, kan udvikle en ny tekst, uadskillelig fra den originale, der udgør en tekstens leg i og med sig selv - ganske som rabbinernes arbejde med Torah aff øder mishnah og mishnah afføder gemara, uden at noget af det samlede tekstmateriale på noget tidspunkt er andet end Torah. Enkelte tekstpassager kan have utallige, og uforenelige, udlægninger. Men pluraliteten er et gode, ikke et onde, for den løses ved, at man må tage hver sin udl:egning i anvendelse overfor hver sin situation; rabbinerens værdsættelse af tekstens pluralitet er samtidig hans forståelse af den. Han lægger ikke mening ind $i$ teksten, men uddrager utallige meninger deraf. Midrash beskrives i rabbinske kredse som »kreativ filologi $\ll$ og $» k r e a t i v$ historiografi $\ll{ }^{63}$

Tilsvarende rabbinerne har Barthes det for øje, at liesehandlingen, sảvel som teksten, er metonymisk:

»Den logik, der styrer teksten, er ikke omsluttende [...] men metonymisk; den aktivitet, der udgøres af associationer, sammenkoblinger og overførsler falder sammen med en frigørelse af symbolsk energi $\kappa^{64}$

Ifølge Barthes befinder betydning sig i et felt af semantisk translokation; translokation er tekstens herskende logik.

For Barthes har teksten overnaturlig status og besidder en egen kraft: »Teksten er en fetisch og denne fetisch begxerer mig. « ${ }^{6.5}$ Derved har teksten fået en besynderlig status af et omnipotent væsen - der minder om den, teksten har for rabbineren: en overmenneskelig kilde til mening, der kraver, at man fornægter alt andet for den, endda ofrer efter dens påbud. End ikke et »jeg « har for Barthes nogen egen eksistens uafhængig af, eller udenfor, teksten: "'Jeg' er i sig selv en pluralitet af andre tekster. «"6r

Torah er skabelsens plan og følgelig endeløs og evig. Skriften må derfor være i enhver henseende kompleks for at rumme dette. Den skriftlige Torah kan derfor ikke adskilles fra den mundilige Torah, der vejleder til at uddrage specifikt gyldige love og principper af teksten. For rabbineren er tekst og exegese en absolut enhed, og modstridende tolkninger kan være lige gyldige. Både tekst og fortolkning er havet over tid og rum, og tekst, metatekst og metametatekst indgår altid i en enhed. Med andre ord: kritikken og metakritikken kan fortsatte i det uendelige, og med en uendelig exegese og uendelig meta-metakritik, og altsammen vil altid vere en del af den oprindelige tekst. Desuden er de exegetiske principper og hermeneutiske regler selv del af den tekst, de retter sig mod. Det er vist det samme, Roland Barthes skriver: 
$»[\ldots]$ En teori om teksten kan ikke ydes fuld retfærdighed ved en metalingvistisk fremstilling. Nedbrydningen af metasprog, eller (siden det kan blive nødvendigt at bruge det af og til) i det mindste at bringe det $i$ tvivl, er en del af teorien selv. Diskurs om Teksten bør selv ikke vare andet end »tekst «, søgen og tekstuelt arbejde, siden Teksten er det sociale rum som [...] ikke tillader noget formidlende eller fremsigende subjekt at indtage en rolle som dommer, lierer, analytiker, skriftefader eller fortolker. Teorien om Teksten kan alene falde sammen med skrivningen. $\ll^{67}$

Teksten peger for rabbinerne ikke hen mod »noget«, men alene mod sig selv, da alt er udgået af dets ord. Ordet peger ikke hen mod en logos, en ontologisk essens, en væren, men er i sig selv slet og ret polysemisk; teksten er selvreferentiel og altid intratextuel, dets ords betydningsindhold uadskilleligt fra et uafgrænseligt kompleks af betydning.

Derrida har samme synspunkt. Han mener, at det at frarøve sproget dets metaforiske, flertydige kvalitet for i stedet at gøre ordet til entydig signifiant for en sprogligt postuleret ontologisk signifié (en tingens væren), er det samme som mytologisering. ${ }^{68}$ Reduktion af polysemi til monosemi er at bogstaveliggøre den metaforiske identitet mellem subjekt og prædikat. Når metaforen bliver gjort bogstavelig, erstattes det fundamentale fravær med nærvær. Narværet er derfor en postuleret væren og vi foregøgler os således at vi taler ontologi, hvor vi igrunden blot jonglerer med metaforer.

Både Derrida og Barthes - sant rabbinerne -, ser teksten som producent af mening, ikke som representant for noget andet udenfor sig selv. Barthes: »Bogen producerer mening; meningen danner liv. $\ll^{69} \mathrm{~V}$ æren kommer således $\mathbf{u}^{-}$ undgåeligt for Barthes efter ordet, ikke før ordet, ganske som for rabbineren. Den mystiske tilskyndelse, Kristus giver i formaningen om at bede i pneuma, da både man selv og Gud er pneuma, er meningsløs ud fra den opfattelse at liv kommer af bogen. Overbevisningen om at bogen er livgiver fortranger enhver beskæftigelse med spørgsmålet om, hvorvidt der overhovdet kan eksistere værens-konstans, om ikke spørgsmålet selv, da spørgsmålet og dets svar på forhånd sættes at vare écriture og dermed funderet i fravier.

Dekonstruktionen kan ikke have et egentlig sæt aksiomer. Imidlertid synes dens sætninger at påberåbe sig en aksiomatisk status (der er intet udenfor teksten; jeget er selv en pluralitet af andre tekster; osv.). Disse pseudo-axiomatiske udsagn er udledt af en negation. Findes der en værenskonstans, så kan den i sagens natur ikke være écriture. Écriture-forestillingen er derfor ikke et argument imod mystikkens sag, men alene et argument for ikke at identificere my- 
stikkens udsagn med mystikkens sag, men se mystikkens udsagn som tentative vidnesbyrd om en uudsigelig erkendelse.

\section{Derrida og skrivemaskinen Jahve}

Derrida går i rette med Saussures tegnteori. Saussure er enig i den traditionelle opfattelse af skriften som noget, der er afledt af talen, men samtidig som noget, der truer det oprindelige nærvær i talen; altså talen som uafhiengig af skriften, men dog skriften som noget, der bryder ind i talen og tilraner sig dens position. Derrida spørger dertil, hvordan noget (skriften), der kun skulle være afledt (af talen), kan have magt til at tilrane sig samme position som det, det er afledt af. Han konkluderer, at der ikke er et klart svar, fordi der er tale om en misforståelse af skriftens status; hans argument derfor er, at et talesprog urørt af skrift er en illusion: sproget har altid varet en skrift (écriture).

Saussures tegnteori erklærer, at sprogets enkeltdele kun får deres mening gennem forskelle. Derrida argumenterer, at for at en mening kan træde frem gennem forskelle, så må det andet (l'autre), det er forskellig fra, være nærværende i det selv (le même). Dette betyder dels, at der ikke kan vare noget absolut nærværende bag sprogsystemet, thi det bygger på nærvær af fravær, ikke nærvær af ordets meningsindhold i ordet. Derridas gådefulde begreb trace instituée er det forudsatte, allerede indstiftede spor, der formår at tilbageholde l'autre i le même. Sproget bliver derfor en arke-skrift (archi-écriture), der konstant skriver sig selv og dækker over, at det ikke er sig selv (at det ikke er noget i sig selv). Sproget æendres derfor fra at være udsagt og referentielt til at være udsiger af sit eget kosmos som det siden giver sig til at tale/skrive om. Ganske som rabbinerens kosmos er udsprunget af ordet og ordet er vejen til at forstå det, samt at der ingen forståelse findes uden i og ved arke-skriften Torah. Derrida finder, at siden fravær er sprogets (tegnets) konstitutive element, så kan man ikke læengere opretholde en simpel forestilling om nærvær, væren, hvorved metafysik og ontologi falder fra hinanden. Derrida finder, at der bag alle filosofiske systemer har varet en metafysisk entitet, der opretholdt systemet (eidos, arché, telos, logos, Gud, osv.). Han finder desuden, at den moderne (dvs. for Heidegger og Saussure) kanditat til posten er sprogsystemet. Derridas mål er at bringe filosofien selv til erkendelse af, at dens søgen efter et nærvar, logos, er frugtesløst.

Men hvis forskel er det meningsbærende, så må vi spørge, om der er forskel pả forskel; om forskellen mellem 'kat' og 'kam' er den samme som forskellen mellem 'kat' og 'kar'. Er der ingen forskel mellem disse forskelle, da kan vi ikke sige forskellen er det meningsdannende; er der en forskel mellem forskel- 
lene, da kan vi ikke sige det meningsdannende er fravær, for der må jo så vaere et narvar af den forskel i forskel, eller af det, der bærer den forskel. Er der ingen forskel på forskel, men vi alligevel erkender meningsdannelsen afhoenger af forskel, så har vi ikke sagt andet, end hvad Saussure i sin tid sagde. Derridas argument afhænger således af, at han sætter forskellen som førsteprincip og af, at der ikke er forskel på forskel, hvorfor han uvilkårligt satter fravær af forskel endnu før forskel. Dermed bliver fravar det egentlige førsteprincip.

På hvilken måde adskiller da Derridas trace og differance sig fra den forkætrede metafysikkens entitet? Han betegner entiteten fravær i stedet for nærvær. Men er han i grunden ikke ude i samme dilemma: at han postulerer et tilstedevær (trace), han ikke kan specificere på behørig vis. Desuden: at benævne det betydningsbærende $»$ fravær er ikke stort anderledes end at benævne det »Det Uudsigelige Ene« (Plotin). Og hvis der er et trace instituée, hvad er det spor institueret i? Derrida har ikke dekonstrueret metafysikkens problem og bragt dens søgen til ende, han har blot eftertrykkeligt fremstillet sprogets magtesløshed overfor netop det metafysiske problem og overfor erkendelsen af væren. Det er der principielt ikke noget nyt $i$, udover at han har fremlagt et bevis, mystikerne har pointeret uudsigeligheden af den mystiske erkendelse i tusinder af år nu. Ikke desto mindre kan vi ikke benægte erkendelsen.

Derrida må tage en konsekvens af sin værensløshed, der i bedste fald kan betegnes pudsig. Hans psykologi består fundamentalt $\mathrm{i}$ at:

»Psykens indhold vil være repræsenteret af en tekst, der i sit viesen er irreducibelt grafisk. Det psykiske apparats struktur vil være repræsenteret af en skrivemaskine. «"

For så vidt er Derrida grafocentrisk (ikke fonocentrisk) i sin åndslære og dermed psykokabbalist. Derridas »pneuma« er ikke Gud eller væren, men et fuldautomatisk tekstbehandlingprogram. Men hvad nedfælder skrivemaskinen sin skrift i? Derrida kan ikke erklare, at der er tale om tekst i tekst, da det vil være enten intetsigende, eller postulere en urtekst som et metafysisk nærvær i stedet for logos. At henvise til neuropsykologi er uholdbart, da dens forhold til det metafysike problemfelt $i$ sit udgangspunkt ikke kan være andet end affejen. Derrida mả da ende med en entitet, der »bare er der «, der må betegnes alene $\gg$ det, der er det, det er «, hvilket selvfølgelig er, hvad ordet »Jahve« betyder. Jahve er således archi-écriturens store udsiger for såvel rabbineren som for Derrida.

Barbara Johnson ${ }^{71}$ har vist, hvordan Derrida selv begår den overmaling af aporier, han angriber $\mathbf{i} \gg$ Mythologie Blanche«; specielt overmaler han den overordnede apori, der udgøres af problemet om signifikans. Hans endeløse 
fæegterier med ord vil tvinge ham til at fæegte bag om selve tegnsystemet, idet tegnsystemet, og specielt hele ideen om en fundamental écriture, kan opfattes som én overordnet signifikator. Men hvad henviser den til? Og hvor făr sproget, som én kompleks signifikator, sin mening fra, hvis det er sådan, at mening kun kommer fra noget andet indsat i det selv? Givetvis ikke ud af ingenting lige så lidt som det erkendes af ingenting. Blev meningsløsheden pludselig til mening? I så fald er såvel signifikansen som erkendelsen eventuel. Hvordan gik dét til? Vi har så endnu en pendant til YHVH, der pludselig ud af ingenting skriver sig med sort flammeskrift og etablerer et alfabet og et kosmos ud af sig selv med samt en tekst til at begribe skabelsessprogets (sprog-)skabelse. Rabbinernes Gud er, i modsætning til de kristnes, en fraværende Gud, - og en Gud, der har ytret skabelsen som ursproglig struktur og givet en tekst som mulighed for at beskæftige sig dermed; hvilken guddommelig skrivemaskine: Jahve! Rabbineren insisterer på, ganske som Derrida udtrykker $\operatorname{det}^{72}$, at der er intet udenfor teksten. Hvorfor skulle rabbineren beskreftige sig med Gud i mystisk forstand, som Absolut Væren, når de har teksten? $?^{73}$

Harold Bloom er på mange måder beslægtet med Derrida, men på afg $\varnothing-$ rende punkter afviger han, f.eks. kommer han om dette problem på ærkerabbinsk vis ved at sige, at Guds første akt var en belæring og den belæring var at skrive. ${ }^{74}$

Spørger vi med Derrida's l'autre i le même, hvad er da dette andet uden for sproget, der indlejret i sproget giver sproget mening? Overfor dette spørgsmảl er der ikke noget svar at hente hos Derrida ud over det ubehjælpsomme teorem, at mennesket er en skrivemaskine. Derrida står da med samme problem som metafysikere altid har stået med, at de kun kan opretholde deres verbalt strukturerede tankekompleks ved at postulere eksistensen af et eller andet uerkendt som grundlag, f.eks. »Gud«»Det Absolutte « etc. Nu, hos Derrida: En skriftautomaton eller et stykke skrivepapir. Med det teorem, at mennesket er en skrivemaskine, som udgangspunkt, er det selvindlysende, at Derrida har det svært med verbet »at være« og med Benvenistes »vi må genetablere den fulde styrke og den autentiske funktion af verbet 'at være'. ${ }^{75}$ Han konkluderer sin diskussion med, at vedrørende »at være« er der ikke mere for filosofien eller lingvistikken at sige. Deri kan han nok have ret, men ironisk nok siger han ikke andet end, hvad de, der bærer vidnesbyrd om, at den metafysiske entitet er direkte erkendbar, har gentaget både sideløbende med, og endda før, den vestlige ontoteologi, dvs. mystikerne. Derridas lukkede dør burde henlede opmærksomheden på den anden dør, der altid har åbnet sig mod den fulde styrke og det autentiske indhold af verbet »at være«: mystikken.

Når jeg hidtil har talt om kristen mystik, så er det selvfølgelig indenfor nonreformert kristendom, dvs. katolsk og orthodoks. Der findes ingen Lutheransk 
mystik, da individets forhold til Gud, for den reformerte, ligger alene i troen, og, bemark: troen kommer af ordet. Det er tankeviekkende, at reformationen definitivt satte tro i stedet for epistemologi og dens senere ikonoklasme satte tegnet, grafemet, i stedet for ikonen. Det kunne viere interessant at lave et sammenlignende studie af ordoopfattelsen i den reformerte kristendom i forhold til Derrida og rabbinerne, samt orientere det om spændingen mellem at vide og at tro, man ved.

Luther fjernede enhver form for potentiel mystik ved at fjerne helgen-begrebet: at man kunne nå enhed med Gud, det guddommelige, allerede i dette liv; den forestilling er naturligvis drivkraften i mystik; megen mystik vil endda sige, at enhed med Gud er en metafor for en ekstrem bevidsthedstilstand, hvor man ontologisk er ét med (det, der ligeså metaforisk, kan benævnes) Det Absolutte Ene.

Det er Luthers misforståelse at tro mystikeren vil blive mere ét med Gud end andre, mystikeren vil blive mere bevidst om den enhed med Gud, vi alle i lige mål har fra fødslen af, og han vil blive det ved direkte erfaring deraf, ikke ved ordet. For den reformerte er pistis - troen - målet, for mystikeren er pistis forudsatningen for at involvere sig i dets medium (meditation og siden mystisk kontemplation). Den mystiske kontemplation er kendetegnet ved at transcendere det konceptuelle apparat. Dette apparat spærrer selvfølgelig for den efterstræbte erkendelse, der kun kan vare en radikal væren; at ens væren er identisk med Guds væren, hvorved man indsér at dualiteten Gud: menneske, er ophavet. Forstadiet til den mystiske kontemplation er, at man praktiserer en meditation, i hvilket man фver sig i at transcendere det diskursive register. Den videnskab, vi i dag ser dekonstrueret under betegnelsen greco-kristen ontoteologi, er i grunden kun kristen i den forstand, at kristendommen er reformert. I den tradition er der ingen plads for den mystiske åbenbaring. Den mystiske åbenbaring transcenderer ordet og logikken ved at åbenbare en varen, der typisk beskrives som forskellig fra forskel. Den tradition, vi nu ser dekonstrueret, er altså i sit vesen ikke logocentrisk, men pisteocentrisk (troscentreret). Den er ikke centreret $\mathrm{i} \operatorname{logos}$, men i en tro på, at logos er der og kan erkendes. Som Derrida påpeger har den logocentriske tradition ikke haft logos, men en sproglig forestilling derom. Dette bekriefter at vi mere rammende kan kalde den pisteocentrisk.

Efter dekonstruktion har vi tre muligheder: Vi kan enten resignere, definere os selv om skriftautomatoner, eller undersøge mystikken. Udgangspunktet for vor undersøgelse af mystikken vil, takket være Derridas dekonstruktion, kunne være opmærksom på ikke at falde i det hul, der udgøres af den vestlige ontoteologis pisteocentriske logocentricitet. Mystikken er ikke et filosofisk projekt beskiftiget med symbolsk orden cller metaforisk erkendelse. Det understreges 
af at mystikere af forskellige kulturer, sociallag og uddannelseslag, og til forskellige tider, kredser om samme erkendelse, og at den kun fremtræder forskelligt, idet den ikliedes sproget. ${ }^{76}$

Men uden en umiddelbar erfaring af Det Absolutte, så fremkommer alt for én alene i og ved forskelle. Ikke-mystikeren opretholder sin hvide mytologi ved at insistere på, at forskellene er sandheden. Vi kan ikke sige, at mystikkens palimpsest er, at alt er ét, for der findes ingen mystisk palimpsest; palimpsest har som forudsintning forskellen. Ikke-mystikerens hvide overmaling af mystikerens ontologiske erkendelse (palimpsesten) vedrører altså alene ikkemystikeren: Mystikeren vil mene, at også overmalingen og forskellen er et varensudtryk. Den anskuelse, der har forskellen (la differance) som førsteprincip, vil altid hvile på en cirkelslutning, thi ud fra sig selv sæetter den distanceringen fra noget andet og den distanceren postuleres siden at være et forudgående førsteprincip. Forud for distanceringen er dog enheden; netop den Enhed, som mystikken bærer et massivt vidnesbyrd om er erkendbar. Filosofien er altså filosofiens egen banemand, som Derrida til fulde har pointeret, men ironisk nok kun endegyldigt har vist indirekte. Hans egen dekonstruktion dekonstruerer sig selv.

Således har vi tre mulgheder:

1) Enten at vende til en alternativ filosofi og alternativ grafocentricitet (som Bloom i hans kabbalistiske system).

2) Blive nihilister - i den forstand, at alt er lige-gyldigt siden intet kan gyldiggøres.

3) Søge ud over hele det felt, der afhæenger af forskellen, dvs. søge ind i mystikken. Dette må vel at mærke være under den forudsætning, at vi med en knivskarp opmærksomhed (der ultimativt, om end ikke indledningsvis, kræver en egen umiddelbart oplevelse af det mystiske Ene) bortrenser den religiøse lage i hvilket de mystiske erkendelser har været nedsyltet $\mathrm{i}$ århundreder for ikke at gå til på inkvisitionens bål eller de reformerte kirkers angst for en ontoteologi, der ikke er pisteocentrisk.

\section{Epilogos - eller efter logos}

Det er blevet vist, at den postmoderne kritik og dekonstruktion af den vestlige filosofis metafysik delvis synes at føre til - og måske til dels kan synes at udspringe af - en anden fraviersmetafysik, der i vid udstrækning kan jævnføres med den rabbinske metafysik i opfattelsen af Jahve og Torah. Det er yderli- 
gere vist, hvordan rabbinsk hermeneutisk metode er uacceptabel indenfor den klassiske vestlige logiks tradition og den græco-kristne ånds- og værensopfattelse, men viser sig at stemme overens med den analyseform, Freud udviklede, eller inddrog, i psykoanalysen. Den er desuden i overensstemmelse med Derridas og Barthes åndsopfattelse.

Spørgsmålet bliver principielt for os: om Freud og Derrida kommer til deres konklusioner ud fra en videnskabelig hhv. filosofisk konsekvens af de respektive vestlige metoder, eller om de i deres arbejde indenfor den vestlige tradition blot har legitimeret deres egne rødder i den jødiske tanketradition. Fortrengte emner har det med at dukke op, og hvor de dukker op, har man som regel meget travt med at legitimere dem som noget andet end det, de oprindeligt var inden fortrængningen (eller: 'l'autre' i 'le même'). Eller er der tale om en naturlig udvikling af vestlig filosofi og videnskab, der tilfældigt fører til et sammenfald mellem med den rabbinske metafysik og hermeneutik?

I forhold hertil står mystikken imidlertid $\mathbf{i}$ alle tilfælde som en udfordring til alle psykokabbalismens former, hvadenten de er dekonstruktion, psykoanalyse eller noget tredie hidtil uset eller hér overset. Med mystikernes tilbagevendende og transkulturelle vidnesbyrd om erkendbar værens-konstans, lader de sig ikke let indfange i hverken vestlig ontologi eller teologi (eller »ontoteo$\operatorname{logi} \ll)$ og slet ikke i dekonstruktionens og psykoanalysens psykokabbalisme.

\section{Noter}

1. W. Benjamin, V. Frankl, E. Levinas, G. Scholem, m.tl. kunne også vare verd at fremhave, men deres rabbinske udspring er ligeledes åbenbart. De behandles mht. det rabbinske af Susan Handelman i Fragments of Redemption, New York 1991, hvori hun valger at se specielt Derrida i forhold til Levinas, Benjamin, mv. frem for i en kontekst af traditionel rabbinsk grafocentricitet. Ang. Bloom, se f.eks. hans Kabbalah and Criticism, N.Y.1975. Bloom set i forhold til Derrida og Kabbalah er andetsteds behandlet af Inge Birgitte Siegumfeldt,jfr. dennes: »Bloom, Derrida and the Kabbalah. The Invocation of Ancestral Voices « in: Orbis Literarum 49, 1994 pp. $307 \mathrm{ff}$. Artiklens baggrund er et Ph.D.projekt ved Odense Universitet om »The Judaization of Postmodern Theory«. Jeg vil gerne takke Inge Birgitte Siegumfeldt for er at have afgivet et responsum til mit første udkast til denne artikel. Frem for judaiseringstemaet har jeg valgt at lagge mit fokus i spændingsområdet mellem tekst og ontologi og pa en kritik af psykokabbalismen ud fra den kristne mystik.

2. Jerusalem Talmud, Bereshit Rabbah 1:1. Min tilføjelse refererer til foregående vers.

3. Kabbalah's rødder fortaber sig i fortiden; det har været, og er i udstrakt grad, en hemmelig esoterisk lære. Se G.Scholem: Origins of the Kabbalah.

4. Vedrørende dette og følgende beskrivelse af kabbalistisk metafysik og kosmologi se Aryeh Kaplan: Meditation and Kabbalah, Maione 1993. Specielt om universer 
i forhold til Adam Kadmon: pp. 209-213 (Ari's opfattelse) samt pp. 293-296 (7 firmamenter).

5. Alexander Samely: »Between Scripture and its Rewording. Towards a Classification of Rabbinic Exegesis«, in Journal of Jewish Studies, XLII.1 (1991), pp. 3968. Vil man se utallige eksempler på hvordan denne grafocentricitet kan have et meditativt udtryk, er hovedvejen dertil Kaplan op.cit. og dens mange citater fra kabbalistiske primartekster.

6. C.Rawidowicz: On Interpretation «, in N.Glatzer (ed.): Studies in Jewish Thought, Philadelphia 1974, p. 52.

7. Susan A.Handelman: The Slayers of Moses: The Emergence of Rablinic Interpretation in Modern Literary Theory, New York 1982, p.64.

8. Samely loc.cit, p.41.

9. Louis Jacobs: Studies in Talmudic Logic and Methology, London 1961, p.4.

10. Handelman op.cit., p.53 f. , hendes fiemhævelser.

11. Argumentet forekommer i Bereishit Rabbah, 43:2. Cit. efter Handelman op.cit, p. 72 .

12. Prooftexts 4,2 (1984). Se endvidere Handelmans replik i Prooftexts 5, 1 (1985), samt Sterns slutbemarkning i samme.

13. Stern loc.cit., p. 198.

14. Jvf. J. Neusner: The Mishnah. An Introduction, Northvale, N.J., 1989, p. 200.

15. En god introduktion til talmud er J.Neusner: Imvitation to the Talmud, N.Y.1973.

16. En god presentation af Midrash er J.Neusner: The Midrash. An Introduction, op. cit.

17. Neusner op.cit., p. 212.

18. Rawidowicz op.cit.

19. Derrida har udtalt: $\gg$ I have never actually invoked the Jewish tradition in any "rooted' or direct manner«, efter Sie gumfeldt: $\gg$ On the Judaization of Postmodern Theory« in: PEO 77, 1994. Det er et besynderligt udsagn. når han samtidig erklierer, med Joyce: »Are we Jews? Are we Greeks? [... ' Jewgreek is greekjew. Extremes meet'« in: Writing and Difference, Chicago 1978, p.153.

20. Følgende opsummering af dets historie er plukket fra forskellige steder i Kaplan op.cit. Se iøvrigt Scholem op. cit.

21. Shevuot 26a.

22. Allerede et tidligt vark barer begrebet som titel: Dionysius (Pseudo-)Aeropagitans: The Mystical Theology, fra slutningen af det 5. årh. omend den først oversattes til engelsk i det 14. ărhundrede af forfatteren til The Cloud of Unknowing. Cf. Andrew Louth: Origins of the Christian Mystical Tradition, N.Y. 1992.

23. Se f.eks. Teresa af Avila. Hendes skrifter er fyldt med advarsler mod enhver form for okkult indsigt. Hun advarer endda mod at beskaftige sig med, overhovedet tage sig af, åbenbaringer af Maria eller Jesus, da de kan vildlede én fra den absolutte, umedierede enhed med Gud.

24. I: Shosan Yesod Olam, 715, 467, 582 og 1109. Cf. Kaplan op.cit., p. 155ff.

25. Maggid Mesharim, BaShalach, 15 Shevat. Cit. efter Kaplan op.cit., p.178.

26. Se f.eks. Eckharts prædiken over Johs. 4,16:

»Gud lever i sjæelen med alt han og alle skabninger er. [..] Hvor min sjel er, der er Gud, og hvor Gud er, der er min sjæl. Dette er så sandt, som at Gud er Gud og: »Sảledes vil begge vasener - kroppens vasen og sjælens vaesen - blive fuldkommengjorte i den ene Kristus som én Gud og én Søn. Begge in Fox, Matthew: Breakthrough. Meister Eckharts Creation Spirituality, N.Y. 1980 (1329), p. 388 
hhv. p.3y1.

27. Sammenlign f.eks. midrash om Højsangen (se f.eks. Neusner The Midrash. An Introduction, op.cit., p.197 ff.) og Johannes af Korsets Spirituelle Højsang (The Spiritual Canticle).

28. I dette støxtter mystikeren sig til Johs. 17.21-23: »[...] at de må vare ét, ligesom du, Fader! i mig, og jeg i dig, at ogsâ de må vare ét i os, så verden må tro, at du har sendt mig. Og den herlighed, du har givet mig, den har jeg givet dem, for at de skal vare ét, ligesom vi er ét, jeg i dem og du i mig, for at de må vare fuldkommen ét. să verden kan forstå, at dı har sendt mig og har elsket dem, ligesom du har elsket mig «. Demme tekst har to udlagninger: den exoteriske, der metaforisk henviser til kirkefallesskabet, og den esoteriske, der tager den bogstavelige betydning for gode varer.

29. William James: Varieties of Religious Experience, N.Y.1985 (1902), p. 405.

30. Vidnesbyrdet herom er overveldende. Tag f.eks. tilfaldige pradikener af Meister Eckhart eller Symeon den Nye Teolog. (Cf.Symeon, The New Theologian: The Discourses, trans. C.J.Catanzaro, New Jersey 1980 (1022)). Se iøvrigt Basil Krivocheine: In The Light of Christ. St. Symeon The New Theologian, trans. Anthony P. Gythiel, N.Y. 1986. Ganske vist kan den kristne mystik deles i flere retninger, men en diskussion af disse vil vare for vidtstrakt her. Jeg laegger den apofatiske og teocentriske mystik til grund for min diskussion (Eckhart, Symeon, Johs. af Korset, in.fl.).

31. $16 a 19$.

32. Kratylos: 423 b.

33. Ibid. $435 \mathrm{a}$.

34. Ibid. 439.

35. Pseudo-Dionysius's liv kan ikke dateres nøjagtigt, men han var antageligt en syrisk munk fra det 5 . årh, der skrev på grask. Hans varker dukker først op i latinsk oversattelse og får udbredelse i vesten med Scot's oversiettelse fra det 9. årh.

36. I. Rabinowitz: "Word and Literature in Ancient Israel, in New Literary History 4 (1972), p.121.

37. Johs. 14:17, $26 \& 16: 13$.

38. Stern in Prooftexts 4,2 1984, p. 202-3

39. Jvf. Gadame1: Truth and Method, N.Y., 1960, p. 423-24.

40. I almindelighed navner man 10, men antallet er for Aristoteles mindre interessant end selve det pradikative klassifikationssystem.

41. Jvf. Todorov: $\gg$ On Linguistic Symbolism«, in New Literary History 6 (1974).

42. Denne pointe er Ricoeurs, jfr. hans The Rule of Metaphor, Toronto 1977.

43. Jacques Derrida: »White Mythology«, in Margins of Philosophy, Chicago 1982. pp. $207-272$.

44. Ibid. p. 228.

45. Ibid. p. 270-71.

46. Poetik. kap. 21, 1457b.

47. Ibid.

48. Ricoeur: The Rule of Metafor op.cit.

49. Freud: Drommetydning, Kbh. 1974 (1900).

50. Berakhot 55.b.

51. J. Lacan: »Insistence of the Letter in the Unconsciouss, in J. Ehrmann (ed.): Structuralism, N.Y. 1970

52. Se David Bakan: Sigmund Freud and the Jewish Mystical tradition, Boston 1975 
(1958).

53. Dette vender igen og igen tilbage i Drømmetydning kap. 6.

54. Følgende tal-eksempel og næste eksempel med Maistollmutz gennemgås (m.f1.) af Handelman i Slayers..., op.cit., p. 149. For en dybere gennemgang, se Bakan op. cit.

55. Drømmetydning, p. 247.

56. Ibid. p. 288.

57. Ibid, p. 263

58. Ibid. p. 278.

59. Se f.eks. Harry Trosman: »Freud's Cultural Background, « in J.E.Gedo et.al. (eds.): Freud. The Fusion of Science and Humanism, N.Y.1976, samt Leon Vogel: »Freud and Judaism. An Analysis in the Light of His Correspondence «, in Judaism 24 (1977), pp. 181-93.

60. Bakan op.cit.

61. Proofterts 4,2 (1984), p.197.

62. S/Z, New York 1974, p. 4.

63. Isaac Heinemann in David Stern: »Moses-cide. Midrash and Contemporary Literary Criticism «, in Prooftexts 4.2 (1984), p. 197.

64. R.Barthes: Image, Music, Text, trans. Stephen Heath, N. Y. 1973, p. 58.

65. R.Barthes: The Pleasure of the Text, trans. Richard Miller. N.Y. 1973, p. 27.

66. S/Z, New York 1974, p. 10.

67. R. Barthes: »From Work to Text N.Y. 1979 , p. 81.

68. Jvf. »White Mythology «, loc.cit.

69. The Pleasure of the Text, op.cit., p. 36.

70. I.Derrida: »Freud and the Scene of Writing «, in Yale French Studies 48 (1972), p. 75.

71. Barbara Johnson: »The Frame of Reference «, in Yale French Studies 55/56 (1977), p. 484.

72. J. Derrida: Of Grammatology, trans. Gayatri Spivak, Baltimore 1976 (1967), p. 158.

73. Cf. Emmanuel Levinas: »To Love the Torah more than God, in Judaism 28 (1963).

74. Bloom: Kabbalah and Criticism, N.Y. 1975. p. 80.

75. »The Supplement of Copula in Margins of Philosophy, op.cit.

76. Se f.eks. F.C. Happold: Mysticism. A Study and an Anthology, Harmondsworth 1990 (1963), pp. 15-122. William James: »Mysticism«, in James op.cit., pp. 379-430. W.T. Stace: Mysticism and Philosoply, London 1961 (1960), f.eks. »The Problem of the Universal Core «pp. 41-133 og »Pantheism, Dualism and Monism« pp. 207-250. Marie Mikhulová Thulstrup: Begrebet Mystik, Kbh. 1974. 